\section{Producing Bio-Based Bulk Chemicals Using Industrial Biotechnology Saves Energy and Combats Climate Change}

\author{
B. G. HERMANN, * K. B L OK, AN D \\ M. K. P A T E L \\ Science, Technology \& Society, Utrecht University, \\ Heidelberglaan 2, 3584 CS Utrecht, The Netherlands
}

The production of bulk chemicals from biomass can make a significant contribution to solving two of the most urgent environmental problems: climate change and depletion of fossil energy. We analyzed current and future technology routes leading to 15 bulk chemicals using industrial biotechnology and calculated their $\mathrm{CO}_{2}$ emissions and fossil energy use. Savings of more than $100 \%$ in nonrenewable energy use and greenhouse gas emissions are already possible with current state of the art biotechnology. Substantial further savings are possible for the future by improved fermentation and downstream processing. Worldwide $\mathrm{CO}_{2}$ savings in the range of $500-1000$ million tons per year are possible using future technology. Industrial biotechnology hence offers excellent opportunities for mitigating greenhouse gas emissions and decreasing dependence on fossil energy sources and therefore has the potential to make inroads into the existing chemical industry.

\section{Introduction}

Bulk chemicals are currently produced almost exclusively from petrochemical feedstocks derived from crude oil and natural gas. Production of the same or functionally equivalent chemicals from renewable resources can decrease the environmental impact, for example, emissions of greenhouse gases. In the light of long-term emission targets, such as the EU target of $15-30 \%$ reduction of $\mathrm{CO}_{2}$ emissions by 2020, as well as increasingly high oil prices, bio-based chemicals may play an important role by contributing toward achieving emission targets, as well as by reducing dependence on expensive fossil resources. New perspectives and opportunities for the production of chemical bulk materials and intermediates from renewable resources have been opened by recent progress in industrial biotechnology (IB), primarily, because of the increased productivities and yields of fermentation. Further substantial progress in this area is expected, especially related to genetically modified microorganisms. Nevertheless the application of IB for the production of bulk bio-chemicals has so far received much less attention than bioethanol for fuel use and energy production from biomass.

IB comprises the production of organic compounds by means of fermentation or enzymatic conversions. In principle, both bio-based and petrochemical feedstocks can be used as raw materials for IB processes, but bio-based

\footnotetext{
* Corresponding author e-mail: b.g.hermann@uu.nl; phone: +31-30-2533145; fax: +31-30-2537601.
}

feedstocks are most commonly used in IB, and petrochemical feedstocks for IB are therefore not considered here. Ragauskas et al. (1) have stated that the conversion of biomass sugars into biomaterials and fuels will be one key feature of future biorefineries. However, environmental assessments related to IB-based bulk chemicals produced from renewable resources are scarce: a number of publications on the environmental impacts of IB-based products are available, but almost all have focused on a single product: predominantly on fuel ethanol $(2,3)$ but also on (poly)lactic acid $(4,5)$, and polyhydroxyalkanoates $(6,7)$. Background assumptions, system boundaries, and methodologies differ among these studies, and the results are not easy to compare. Furthermore, future technology improvement is disregarded although it may substantially reduce the environmental impacts of bulk chemicals from IB. To overcome this problem, we have developed and applied a generic approach that allows estimation of the inputs of feedstock and energy and the associated emissions and costs $(8,9)$.

Earlier analysis based on this generic approach has shown that IB-based chemicals have economic advantages over their petrochemical counterparts for fermentable sugar prices even above current market prices (9). Here we quantify environmental impacts of the production of one ton of chemical using current and future technology IB. We do this according to the principles of life-cycle assessment, that is, covering the entire process chain starting from the extraction of resources.

\section{Methodology}

The goal of this study was to analyze the environmental performance of producing bulk chemicals from biomass using industrial biotechnology (IB) considering current and future (2030) technology and to compare it with bulk petrochemicals. We focus exclusively on the use of the selected products as chemicals and exclude their use as fuels and animal feed. Following the principle proposed by Landucci and Lynd $(10,11)$, we simulate large-scale industrial processes based on IB by modeling the conversion of fermentable sugar to the target IB chemical using standard modules such as fermentation, filtration, and distillation (see ref 9 for a more detailed description). For each production route, mass and energy balances were determined at the level of unit processes, and a common database for all process inputs was used. Our generic approach therefore allows standardized comparisons between different processes based on a small number of input data.

2.1. Functional Unit and Product Selection. The functional unit is one ton of chemical. The selection of products in this paper was based on three criteria: (1) a feasible fermentation process, (2) available information on the stoichiometry of this process, and (3) the potential to be sold in bulk quantities in the medium or long term (see refs 8 and 9 for details). The following 10 products were studied: 1,3propanediol (PDO), acetic acid, acrylic acid, adipic acid, butanol (from the ABE process), ethanol, lysine, lactic acid, polyhydroxyalkanoates (PHA), and succinic acid. In addition, five products were included that are formed by subsequent chemical conversion of these products: caprolactam, ethyl lactate, ethylene, polylactic acid (PLA), and polytrimethylene terephthalate (PTT).

2.2. System Boundaries. In this study, environmental assessments were carried out for the systems cradle-to-factory gate and cradle-to-grave. We only present results for the latter because it is comprehensive since it includes waste management. To evaluate the environmental effects of these 


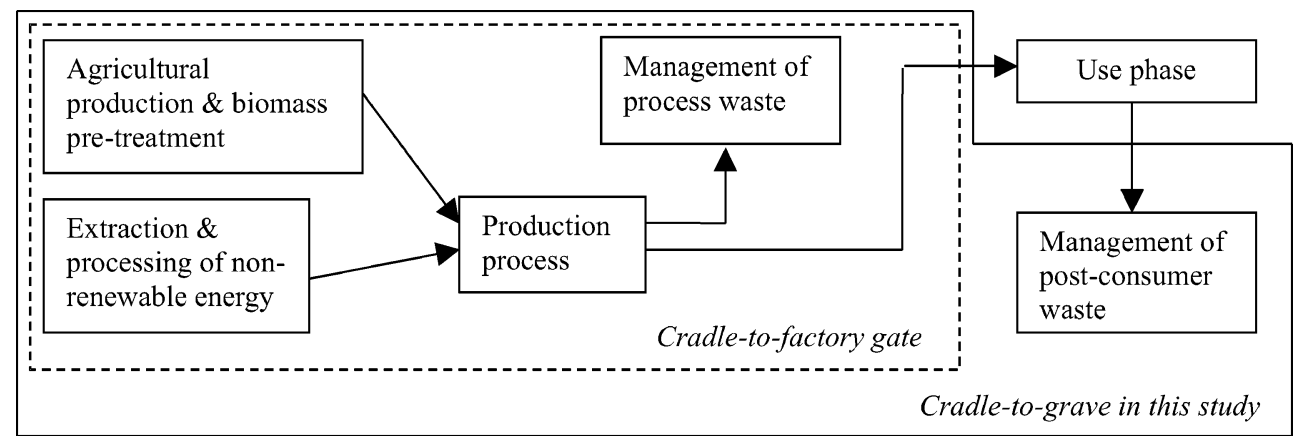

FIGURE 1. Subsystems and system boundaries considered within the environmental assessment for bio-based and petro-based chemicals.

chemicals, an assessment across the whole life cycle (cradleto-grave) of the products is necessary. Five subsystems were distinguished when modeling the life cycle (see Figure 1): (1) extraction of non-renewable energy resources such as crude oil, (2) agricultural production and biomass pretreatment, (3) bioprocess (the actual production process), (4) process waste management, and (5) post-consumer waste management.

The use phase was excluded because it is usually identical for comparable bio-based and petrochemical products (e.g., a given plastic component in a passenger car); as a further argument, bulk chemicals usually do not lead to emissions during this phase. A more detailed description of the subsystems can be found in the Supporting Information.

2.3. Allocation and System Expansion. For all multifunctional processes resulting in more than one product, a method must be chosen that allows expression of the environmental impact relative to the functional unit chosen. The two most commonly used methods are system expansion and allocation. Typical system expansion accounts for a coproduct by expanding the system analyzed to include also the production of the coproduct by alternative means. This approach changes the functional unit to one ton of desired chemical plus amount $x$ of coproduct. To carry out system expansion but limit the functional unit to one ton of desired chemical, we introduce credits representing the avoided impacts related to the manufacture of coproducts (see 12). In general, system expansion is used when the coproduct (e.g., electricity from bagasse) can also be produced by a stand-alone process (e.g., electricity from coal). Allocation on the other hand has to be used when there is no standalone production process, such as corn stover (which can only be produced in conjunction with corn). Allocation is mostly done through mass or economic allocation, that is, by partitioning the overall environmental impact either according to the mass ratio or the price ratio of coproducts.

For this study, allocation and system expansion were relevant for the production of fermentable sugar, the joint production of materials and energy, and the joint production of coproduct chemicals in the fermentation step. We used system expansion whenever energy was produced from coproducts within any of the subsystems. Energy credits were assigned to these systems equal to the amount of nonrenewable energy that would have been used for the production of the respective amount of electricity or steam. For example, the credit for the energy produced from burning waste biomass originating from the bioprocess resulted in an energy credit. This was deducted from the inputs of nonrenewable energy because this energy displaced the use of non-renewable energy, for example, electricity from the grid. System expansion was also used to deal with coproducts of fermentation: all inputs to fermentation were added, and credits were introduced for the coproducts (e.g., acetone and ethanol in the case of $\mathrm{ABE}$ ). These credits were equal to the petrochemical production of these coproducts because
IB coproducts were assumed to displace chemically identical petrochemicals. Allocation was only used in the production of fermentable sugars (see section 3.1).

2.4. Environmental Indicators. A full life cycle assessment (LCA) includes calculation of a range of environmental impacts including acidification, eutrophication, particulate emissions, human toxicity, and environmental toxicity. However, the study presented here is a prospective environmental assessment dealing with future processing routes, and this study uses proxies for the overall environmental impact: non-renewable energy use (NREU), greenhouse gas emissions (GHG), and land use, which may become scarce resources. These indicators were calculated for all IB products and are good proxies for the overall environmental impact.

NREU represents a straightforward and practical approach because many environmental impacts are related to energy use (13). NREU encompasses fossil and nuclear energy and was expressed as higher heating value (HHV), also called the gross calorific value. In line with LCA methodology, the NREU values reported here represent the cumulative energy demand for the system cradle-to-grave.

Greenhouse gas emissions are of growing importance because of the increasing attention paid to the greenhouse effect in the policy arena, by companies, and by the public. GHG emissions were calculated in $\mathrm{CO}_{2}$ equivalents and consist of $\mathrm{GHG}$ emissions from the system in the form of $\mathrm{CO}_{2}$ or $\mathrm{CH}_{4}$, as well as nitrous oxide $\left(\mathrm{N}_{2} \mathrm{O}\right)$ from fertilizer use in biomass production. $\mathrm{CO}_{2}$ emissions from renewable carbon extracted from the atmosphere during plant growth were excluded.

Land use refers to agricultural land use only and will be of increasing importance in the future because of the growth of land requirements for bio-based energy, liquid biofuels, bio-based chemicals, and food and feed production. We neglected the land requirements for industrial plants, for transportation infrastructure, and for waste management because they are small compared with agricultural land use and are comparable for bio-based and petrochemical products.

\section{Life Cycle Inventory}

The availability of process data for assessing IB processes is often very limited, and therefore, a generic approach was developed. A uniform methodology and a common dataset were used to systematically evaluate the environmental aspects of producing bio-based bulk chemicals according to the principles of life cycle assessment (see 14). We refer to ref 9 for a general description of the generic approach and will focus on specific features of the methodology that are especially relevant to the environmental analysis. Environmental impacts were quantified starting from mass and energy inputs to all subsystems considered for the system boundaries. Inputs to the bioprocess system include fermentable sugar, auxiliaries, (bio)catalysts, and utilities. Outputs include the product, coproducts, waste biomass, 
and wastewater. For the generic approach, the amount of inputs and outputs of bioprocesses were calculated using mass balances derived from process flow diagrams (see 9). Each input and output was characterized by its calorific value (HHV in GJ/t product), the cumulative energy use for its production, its embodied carbon, the inputs' cumulative GHG emissions, and the land use required for agricultural production. The Excel database on inputs and outputs included 20 petrochemical feedstocks/intermediates, 7 bio-based feedstocks and intermediates, approximately 30 auxiliaries, 10 catalysts, 10 utilities and fuels, 5 types of waste, its management and energy recovery, and 5 polymers. The data on petrochemicals used as auxiliaries represents current technology and stems from industry (15) and from our calculations based on ref 16 . These datasets were then used to calculate the cumulative GHG emissions, non-renewable energy, and land use by adding up the respective data of all process inputs.

3.1. Production of Fermentable Sugar. Three types of fermentable sugar were considered for the environmental analysis: glucose from corn starch, sucrose from sugar cane, and fermentable sugars from lignocellulosics. A sensitivity analysis on the effect of default and sensitivity cases for fermentable sugars is included in the Supporting Information.

Glucose $\left(\mathrm{C}_{6} \mathrm{H}_{12} \mathrm{O}_{6}\right)$ from corn is produced using enzymes to hydrolyze corn starch. The dataset was derived from the literature $(17,18)$. For agricultural production, the environmental impacts were split between corn and corn stover removed from the field through an economic allocation using a price ratio of $4: 1$ for corn compared to stover. Fermentable sugars from corn starch were assumed to stem from a modern corn wet mill by hydrolysis of starch to dextrose. A detailed mass-based coproduct allocation took into account the subprocesses that were required for the production of these coproducts of fermentable sugar from corn (see also 18). After the coproducts are accounted for, the net input is 1.06 $\mathrm{kg}$ of dry corn for $1 \mathrm{~kg}$ of glucose. The sensitivity case requires higher non-renewable energy use for corn production (derived from 19).

Milling of sugar cane results in sucrose $\left(\mathrm{C}_{12} \mathrm{H}_{22} \mathrm{O}_{11}\right)$ and bagasse. The dataset was calculated from the literature $(20$, $21)$. Wet sugar cane $(8.7 \mathrm{~kg})$ is required to produce $1 \mathrm{~kg}$ of sucrose. Bagasse is burnt to generate energy because it is a low-value product with limited use. Therefore, we used the total factory input of sugar cane as starting point in the default allocation and assigned credits for energy produced from bagasse. For a sensitivity case, we assumed that bagasse is used as animal feed and we assigned $20 \%$ of the overall environmental burden to bagasse based on the ratio of the economic value of sugar to bagasse.

Fermentable sugars from woody biomass, also referred to as $\mathrm{C}_{5} / \mathrm{C}_{6}$ sugars, are typically a mixture of glucose, xylose, and smaller quantities of other sugars obtained through depolymerization of cellulose and hemicellulose. We assumed the production of $\mathrm{C}_{5} / \mathrm{C}_{6}$ sugars from corn stover and derived the dataset from the literature (22). The main purpose of the cultivation of corn has been and will be the production of starch from corn kernels. The default case for allocating inputs for the agricultural production to corn stover is therefore an economic allocation using a price ratio of $4: 1$ for corn compared to stover. The production of 1 ton of fermentable sugar requires 1.79 tons of corn stover. We assumed an energy credit approach in which environmental credits from surplus energy production were subtracted from total inputs for the conversion of corn stover to fermentable sugar. The sensitivity case consists of fermentable sugars from siscanthus.

3.2. Assumptions for the Fermentation Process. In the estimation of the mass balance of the fermentation process, the flows of all compounds are estimated based on yields,

\section{TABLE 1. Summary of Background Data for 1 Ton of} Fermentable Sugar ${ }^{a}$

\begin{tabular}{llrrrr}
\multicolumn{1}{c}{ sugar source } & & $\begin{array}{c}\text { NREU } \\
(\mathbf{G J} / \mathbf{t})\end{array}$ & $\begin{array}{c}\text { REU } \\
(\mathbf{G J} / \mathbf{t})\end{array}$ & $\begin{array}{c}\mathbf{G H G} \\
\left(\mathbf{t} \mathbf{C O}_{\mathbf{2}} / \mathbf{t}\right)\end{array}$ & $\begin{array}{c}\text { LU } \\
(\mathbf{h a / t})\end{array}$ \\
corn starch & default & 6.2 & 17.3 & 0.40 & 0.13 \\
& sensitivity & 10.3 & 17.3 & 0.63 & 0.13 \\
sugar cane & default & -12.8 & 41.8 & -0.54 & 0.13 \\
& sensitivity & 1.4 & 33.4 & 0.11 & 0.10 \\
lignocellulosics & default & -4.4 & 29.2 & 0.16 & 0.05 \\
& sensitivity & -4.0 & 34.3 & 0.04 & 0.13
\end{tabular}

${ }^{a}$ Negative values imply net NREU or GHG savings because the credits for energy production were larger than the NREU or GHG emissions for sugar production.

productivity, and broth concentration of the fermentation step (see 9). The three types of fermentable sugar are assumed to be interchangeable as feedstock ( $1 \mathrm{t}$ glucose $=1 \mathrm{t}$ sucrose $=1 \mathrm{t}$ fermentable sugar from corn stover), implying that the yield for all bioprocesses studied is independent of the type of sugar. However, this is a simplification, because the microorganisms involved in the biotechnological conversion of fermentable sugar to the desired chemical are most often engineered for a specific feedstock such as glucose. (Ethanol has already been produced from $\mathrm{C} 5 / \mathrm{C} 6$ on laboratory scale (26), but with today's technology, only C6 sugars can be converted to the target chemicals on an industrial scale. These sugars are commonly produced from (1) starch crops, such as corn and from (2) sugar crops, such as sugar cane.) The direct conversion of mixtures of pentoses and hexoses $\left(\mathrm{C}_{5} /\right.$ $\mathrm{C}_{6}$ ) sugars to target molecules will therefore require additional efforts in $R \& D$ before it can be implemented for a wide range of IB products and with the same yields and productivities as from pentoses or hexoses only. We thus assumed that the conversion of $\mathrm{C}_{5} / \mathrm{C}_{6}$ sugars produced from lignocellulosic feedstocks such as corn stover to desired products will be possible on an industrial scale in the future, but not today.

3.3. Industry Data for IB Products. For some products, it was possible to compare the results obtained from the generic approach with confidential information on industrial IB processes. Such industry data was provided by DuPont for PDO (24), by NatureWorks (25) and Shell (26) for lactic acid and by A\&F for PHA (27). Ethanol, lysine, and succinic acid were derived from process analyses $(28-30)$. We used aggregated information on inputs to and outputs from the bioprocess to carry out the environmental assessment, following the same methodology and system boundaries as for generic IB routes.

3.4. Petrochemical Data for Benchmarking. IB chemicals were assessed by comparing them with chemically identical or functionally equivalent petrochemical products. Data on the production of petrochemical equivalents of the IB products analyzed represent conventional current technology. Petrochemical data was available for acetic acid, acrylic acid, adipic acid, $n$-butanol, caprolactam, ethyl acetate (benchmark for ethyl lactate), ethylene, maleic anhydride (benchmark for succinic acid), 1,3-propanediol, high-density polyethylene (HDPE; benchmark for PHA), polytrimethylene terephthalate (PTT), and polyethylene terephthalate (PET; benchmark for PLA). The respective data stems from the literature $(15,16,24,31)$. We applied the same system boundaries and methodology to carry out the environmental assessment of the petrochemical benchmark data as for the IB routes.

\section{Results}

The environmental impacts of the processes studied depend to a large extent on the productivities, yields, and concentrations assumed for the fermentation stage $(8,9)$. To assess the 


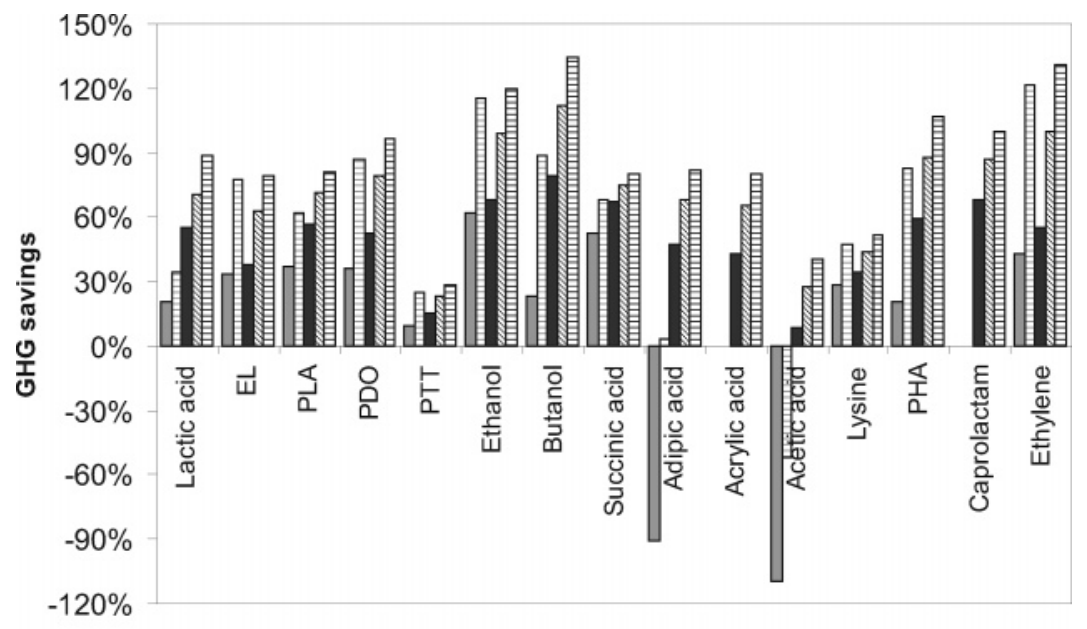

$\square$ Today-Starch $\boxminus$ Today-Cane $\square$ Future-Starch $\mathbb{\mathbb { Q }}$ Future-Ligno 目Future-Cane

FIGURE 2. Greenhouse gas emission savings per ton of IB chemical compared with their petrochemical counterparts for current and future technology cradle-to-grave.

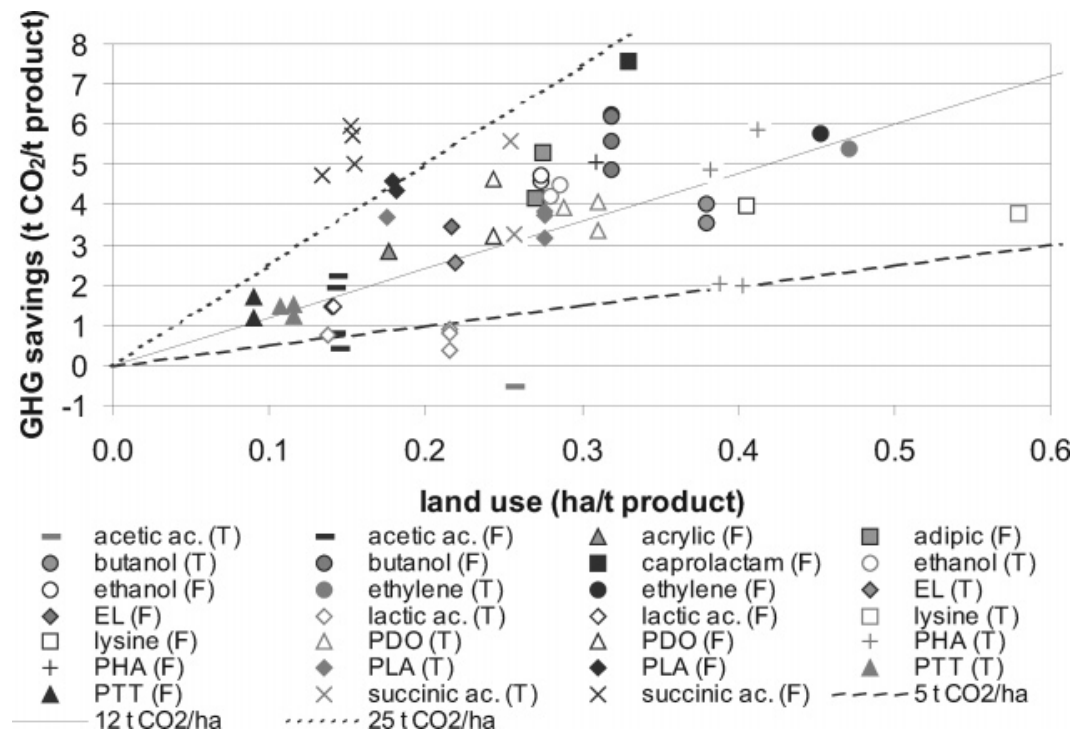

FIGURE 3. Fermentable sugar from sugar cane: Greenhouse gas (GHG) savings versus land use for current (T) and future (F) technology IB production routes per ton of chemical (cradle-to-grave). Straight lines are iso-lines representing $\mathrm{CO}_{2}$ savings per hectare.

long-term potential of IB, we chose future parameter values that are expected to be reached after 20-30 years of successful research and development (horizon values). In this paper, we present results only for GHG emissions, but results for NREU show the same pattern (see 8 ). Figure 2 shows a product by product analysis of average GHG savings in IB products compared with their petrochemical equivalents. Each bar in Figure 2 represents the arithmetic mean across several IB production routes for the same chemical.

Figure 2 shows that the products with the highest relative savings are ethanol, butanol, and ethylene, and acetic acid and PTT have lowest savings. Differences between best cases and arithmetic means were $7-20 \%$ in GHG savings. Figure 2 shows that almost all products promise GHG savings for current technology. For PHA and adipic acid, this depends on the source of fermentable sugar. Acetic acid offers no savings using current technology because of low broth concentration and low productivity in fermentation, as well as high utility use in downstream processing because of the difficulty of separating acetic acid from water (azeotropic mixture). GHG savings for PTT are low because this polymer is made from PDO and purified terephthalic acid, with the latter being produced from petrochemical feedstocks. GHG savings for sugar cane as the source of fermentable sugar are clearly higher than for cornstarch because of the coproduction of significant amounts of electricity which can be exported (see section 2). Figure 2 shows that to maximize greenhouse gas savings for IB products sugar cane is favored over lignocellulosics, which in turn is preferable to corn starch as source of fermentable sugar. In temperate climates such as Europe and North America, where sugar cane is not available from domestic production, lignocellulosics should be the preferred future feedstock.

In some of the IB lignocellulosics and sugar cane cases, the savings are larger than $100 \%$ (Figure 2) because the energy credits from co-combustion of waste biomass or from sidestreams of agricultural production were larger than the GHG emissions for the IB process chain (see section 2). On average, GHG savings for future IB technology are 25-35\% higher than for current IB technology. This shows that technological progress can further enhance the environmental advantage of IB products over their petrochemical equivalents. Low GHG emissions of a process may be caused by (1) high product yield from fermentation or (2) low product yield from fermentation combined with large energy credits from subsequent combustion of coproduced biomass. In the second case, the inefficient fermentation processes require considerably more land for biomass production than efficient 


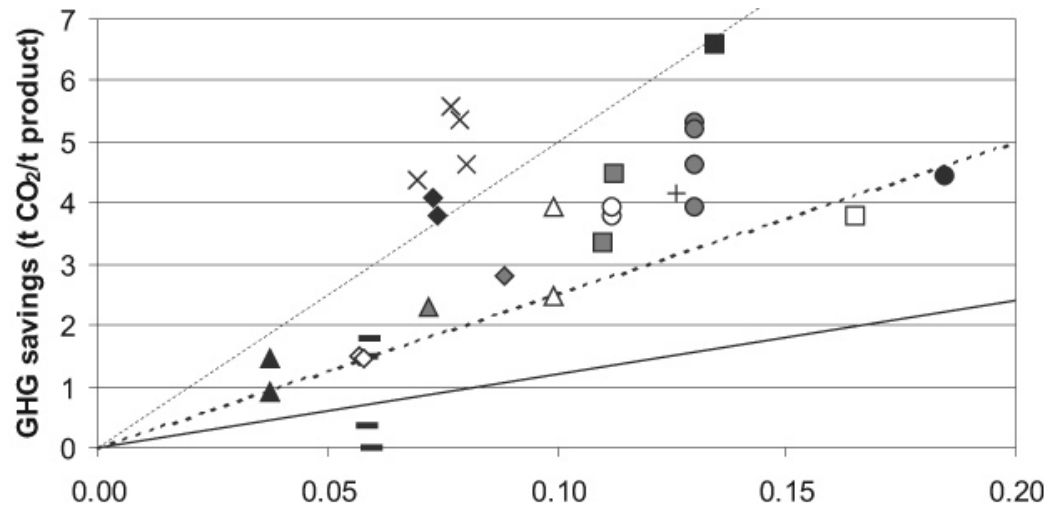

land use (ha/t product)
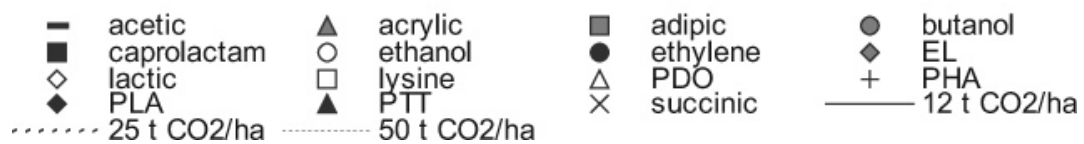

FIGURE 4. Fermentable sugar from corn stover (lignocellulosics): greenhouse gas (GHG) savings versus land use for future technology IB production routes (system cradle-to-grave). Straight lines are iso-lines representing $\mathrm{CO}_{2}$ savings per hectare.

fermentation does. If land availability becomes limited, GHG savings should be maximized for a given amount of land, or alternatively, land use should be minimized for a certain amount of GHG to be saved. Figure 3 therefore simultaneously analyzes GHG savings in all IB-routes relative to the petrochemical route and land use per ton of chemical.

Figure 3 shows that there is a relationship between the type of chemical and the amount of land use for its production from sugar cane. For the production of one ton carboxylic acids $0.1-0.2$ ha land are required, whereas the alcohols are in the range of $0.25-0.35 \mathrm{ha} / \mathrm{t}$. For PTT, land use and GHG savings are low because only a part of this polymer is produced from bio-based feedstocks. Putting GHG savings and low land-use first, succinic acid, caprolactam, PLA, and butanol are the most attractive. Our results compare well with data from publications on individual products $(2-7)$ when accounting for differences in allocation methodology. Producing fuel ethanol from sugar cane results in savings of $10-16 \mathrm{t} \mathrm{CO}_{2, \mathrm{eq}} / \mathrm{ha}$ (8). Several IB chemicals show $\mathrm{CO}_{2}$ savings above $16 \mathrm{t} \mathrm{CO}_{2, \mathrm{eq}} / \mathrm{ha}$ and are therefore preferable from the point of view of $\mathrm{CO}_{2}$ mitigation.

Figure 4 only shows future technology because the commercial production of fermentable sugars from lignocellulosics is not yet possible on a large scale. The comparison of Figures 3 and 4 shows that land-use efficiency in terms of $\mathrm{CO}_{2}$ savings per hectare is much better for corn stover than for sugar cane. Conversion of corn stover to chemicals using future technology almost always results in $\mathrm{CO}_{2}$ savings above $25 \mathrm{t} / \mathrm{ha}$. Biomass for electricity use saves approximately $12 \mathrm{t} \mathrm{CO}_{2 \text {,eq }}$ /ha for whole crop wheat (32) and using lignocellulosics for fuel ethanol production saves $2-7 \mathrm{t} \mathrm{CO}_{2 \text {,eq }} /$ ha (33). (GHG savings from ethanol here are $\sim 33+\mathrm{CO}_{2, \text { eq }} /$ ha because of the reference system: chemical ethanol replaces ethanol produced via ethylene, whereas fuel ethanol replaces gasoline.) Putting $\mathrm{CO}_{2}$ savings first, this implies that most chemicals are preferred over bioenergy if sugar cane is used as feedstock, and almost all chemicals are preferred if using corn stover.

Table 2 quantifies GHG savings potentials, assuming full substitution of the petrochemical equivalents and based on world production capacities in the years 1999/2000 (34). The total saving potential for the future according to Table 2 (510 million tons $\mathrm{CO}_{2 \text {,eq }}$ for corn starch) disregards growth of the chemical industry. The future saving potential is even higher if lignocellulosics (820 million tons $\mathrm{CO}_{2, \text { eq }}$ ) or sugar cane (1030 million tons $\mathrm{CO}_{2, \text { eq }}$ ) are used as feedstocks. For comparison,

\section{TABLE 2. Potential Worldwide Annual Production and Best Case GHG Savings of the 15 IB Products, Using Corn Starch as Feedstock from Cradle to Grave}

\begin{tabular}{|c|c|c|c|c|}
\hline product & & $\begin{array}{c}\text { GHG } \\
\text { savings } \\
\text { (t CO2/t) }\end{array}$ & $\begin{array}{c}\text { installed } \\
\text { world capacity } \\
\text { (34) (kt/year) }\end{array}$ & $\begin{array}{c}\text { annual } \\
\text { GHG } \\
\text { savings } \\
\text { (kt } \mathrm{CO}_{2} / \\
\text { year) }\end{array}$ \\
\hline acetic acid & $\begin{array}{l}\text { today } \\
\text { future }\end{array}$ & $\begin{array}{r}-2.4 \\
1.2\end{array}$ & 8300 & $\begin{array}{r}\text { NA } \\
9570\end{array}$ \\
\hline acrylic acid & future & 1.5 & 2900 & 4380 \\
\hline adipic acid & $\begin{array}{l}\text { today } \\
\text { future }\end{array}$ & $\begin{array}{r}-5.2 \\
3.3\end{array}$ & 2400 & $\begin{array}{r}N A \\
7880\end{array}$ \\
\hline butanol & today & $\begin{array}{l}1.2 \\
39\end{array}$ & 2460 & 3040 \\
\hline caprolactam & future & 5.2 & 3900 & 20100 \\
\hline ethanol & $\begin{array}{l}\text { today } \\
\text { future }\end{array}$ & $\begin{array}{l}2.7 \\
2.7\end{array}$ & 2600 & $\begin{array}{l}6970 \\
7080\end{array}$ \\
\hline ethyl lactate & today & 1.3 & $\begin{array}{r}1200 \\
\text { ethvl acetate }\end{array}$ & $\begin{array}{l}1580 \\
2220\end{array}$ \\
\hline ethylene & $\begin{array}{l}\text { today } \\
\text { future }\end{array}$ & $\begin{array}{l}1.9 \\
2.5\end{array}$ & 100000 & $\begin{array}{l}191050 \\
245710\end{array}$ \\
\hline lysine & $\begin{array}{l}\text { today } \\
\text { future }\end{array}$ & $\begin{array}{l}2.1 \\
3.6\end{array}$ & 640 & $\begin{array}{l}1370 \\
2280\end{array}$ \\
\hline succinic acid & $\begin{array}{l}\text { today } \\
\text { future }\end{array}$ & $\begin{array}{l}4.5 \\
5.0\end{array}$ & $\begin{array}{r}1350 \\
\text { maleic } \\
\text { anhydride }\end{array}$ & $\begin{array}{l}6070 \\
6780\end{array}$ \\
\hline 1,3-propanediol & $\begin{array}{l}\text { today } \\
\text { future }\end{array}$ & $\begin{array}{l}1.8 \\
2.9\end{array}$ & no data & $\begin{array}{l}\text { NA } \\
\text { NA }\end{array}$ \\
\hline $\begin{array}{l}\text { polyhydroxy- } \\
\text { alkanoates }\end{array}$ & today & 2.9 & 57000 & 162730 \\
\hline $\begin{array}{l}\text { polylactic acid } \\
\text { total }\end{array}$ & $\begin{array}{l}\text { future } \\
\text { today } \\
\text { future } \\
\text { today } \\
\text { future }\end{array}$ & $\begin{array}{l}2.8 \\
2.3 \\
3.3\end{array}$ & $\begin{array}{r}\text { polyethylene } \\
11100 \\
\text { PET }\end{array}$ & $\begin{array}{r}159640 \\
25150 \\
36500 \\
397960 \\
511780\end{array}$ \\
\hline
\end{tabular}

current technology production of the petrochemical equivalents lead to emissions of 880 million tons $\mathrm{CO}_{2 \text {,eq }}$ for the same installed capacity and system boundaries. This shows that the potential GHG savings for current technology and corn starch as feedstock already reach $45 \%$.

In summary, even at present, bio-based bulk chemicals from industrial biotechnology offer clear savings in nonrenewable energy use and GHG emissions with current technology compared to conventional petrochemical production. Substantial further savings are possible for the future by improved fermentation and downstream processing. Of 
all feedstocks, sugar cane is to be favored over lignocellulosics, which in turn is preferable to corn starch as source of fermentable sugar to maximize savings. The products with the highest savings are acrylic acid, butanol (from ABE process), ethanol, ethylene, PDO, and PHA.

From a policy perspective, environmental advantages make the production of bio-based bulk chemicals using industrial biotechnology desirable on a large-scale, because savings of more than $100 \%$ in non-renewable energy use and greenhouse gas emissions are already possible at the current level of biotechnology. This builds a strong case for the production of bio-based bulk chemicals using industrial biotechnology considering the economic advantages of 1,3propanediol, polytrimethylene terephthalate, succinic acid, and ethanol for current technology and of all products except acetic acid for future technology (see 9). As a consequence, using industrial biotechnology to produce bio-based chemicals can contribute significantly to the reduction of climate change and the depletion of fossil energy. It is therefore a key strategy for sustainable development of the chemical industry.

\section{Abbreviations}

$\begin{array}{ll}\text { ABE } & \text { acetone-butanol-ethanol } \\ \text { EL } & \text { ethyl lactate } \\ \text { GHG } & \begin{array}{l}\text { greenhouse gas } \\ \text { GJ }_{\mathrm{e}}\end{array} \\ \text { electric energy (GJ) } \\ \text { HDPE } & \text { primary energy (GJ) } \\ \text { high-density polyethylene } \\ \text { HHV } & \begin{array}{l}\text { high heating value, also called gross calorific } \\ \text { value }\end{array} \\ \text { IB } & \text { industrial biotechnology } \\ \text { NREU } & \text { non-renewable energy use } \\ \text { PDO } & \text { 1,3-propanediol } \\ \text { PET } & \text { polyethylene terephthalate } \\ \text { PHA } & \text { polyhydroxyalkanoates } \\ \text { PLA } & \text { polylactic acid } \\ \text { PTT } & \text { polytrimethylene terephthalate } \\ \text { R\&D } & \text { research and development }\end{array}$

\section{Acknowledgments}

This research was mainly supported by the European Commission (Research Directorate General), 5 Framework European Network (GROWTH) Program, by Contract G5MACT-2002-00014.

\section{Supporting Information Available}

A description of the subsystems, calculation results, Tables 3-5 listing non-renewable energy use, greenhouse gas emissions, and land use, a comparison of the results, and the sensitivity analysis and discussion. This material is available free of charge via the Internet at http://pubs.acs.org.

\section{Literature Cited}

(1) Ragauskas, A. J.; Williams, C. K.; Davison, B. H.; Britovsek, G.; Cairney, J.; Eckert, C. A.; Frederick, W. J.; Hallett, J. P.; Leak, D. J.; Liotta, C. L.; Mielenz, J. R.; Murphy, R.; Templer, R.; Tschaplinski, T. The Path Forward for Biofuels and Biomaterials. Science 2006, 311 (5760), 484-489.
(2) Kim, S.; Dale, B. E. Environmental aspects of ethanol derived from no-tilled corn grain: Nonrenewable energy consumption and greenhouse gas emissions. Biomass Bioenergy 2005, 28 (5), 475-489.

(3) Sheehan, J.; Aden, A.; Paustian, K.; Killian, K.; Brenner, J.; Walsh, M.; Nelson, R.. Energy and environmental aspects of using corn stover for fuel ethanol. J. Ind. Ecol. 2003, 7 (3-4), 117-146.

(4) Vink, E. T. H.; Rábago, K. R.; Glassner, D. A.; Gruber, P. R. Applications of life cycle assessment to NatureworksTM polylactide (PLA) production. Polym. Degrad. Stab. 2003, 80 (3), 403-419.

(5) Bohlmann, G. M. Biodegradable packaging life-cycle assessment. Environ. Prog. 2004, 23 (4), 342-346.

(6) Kim, S.; Dale, B. E. Life cycle assessment study of biopolymers (PHA)-derived from no-tilled corn. Int. J. LCA 2005, 10 (2), 200210.

(7) Akiyama, M.; Tsuge, T.; Doi, Y. Environmental life cycle comparison of polyhydroxyalkanoates produced from renewable carbon resources by bacterial fermentation. Polym. Degrad. Stab. 2003, 80 (1), 183-194.

(8) Patel, M.; Crank, M.; Dornburg, V.; Hermann, B. G.; Roes, L.; Hüsing, B.; Overbeek, L.; Terragni, F.; Recchia, E. Medium and long-term opportunities and risks of the biotechnological production of bulk chemicals from renewable resources-The potential of White Biotechnology. The BREW Project; Technical report; Utrecht University: Utrecht, The Netherlands, 2006.

(9) Hermann, B. G.; Patel, M. Today's and tomorrow's bio-based bulk chemicals from white biotechnology-a techno-economic analysis. Appl. Biochem. Biotechnol., 2007, 136, (3) 361-388.

(10) Landucci, R.; Goodman, B.; Wyman, C. E. Methodology for evaluating the economics of biologically producing chemicals and materials from alternative feedstocks. Appl. Biochem. Biotechnol. 1994, 45/46, 677-696.

(11) Lynd, L. R.; Wang, M. Q. A product non-specific framework for evaluating the potential of biomass-based products to displace fossil fuels. J. Ind. Ecol. 2004, 7 (3-4), 17-32.

(12) Weidema, B. Avoiding coproduct allocation in life-cycle assessment. J. Ind. Ecol. 2000, 4 (3), 11-33.

(13) Huijbregts, M. A. J.; Rombouts, L. J. A.; Hellweg, S.; Frischknecht, R.; Hendriks, A. J.; van de Meent, D.; Ragas, A. M. J.; Reijnders, L.; Struijs, J. Is cumulative fossil energy demand a useful indicator for the environmental performance of products? Environ. Sci. Technol. 2006, 40 (3), 641-648.

(14) Life cycle assessment (LCA) principles and framework; Goa and scope definition and inventory analysis; Life cycle impact assessment; Environmental Management Systems; Technical Report ISO 14040-14043; International Standard Organisation: Geneva, 1997-2000.

(15) PEP Yearbook International. Process Economics Program; SRI Consulting: Menlo Park, CA, 2000; Vol. 2M-Germany.

(16) Patel, M.; Jochem, E.; Marscheider-Weidemann, F.; Radgen, P. von Thienen, N. C-STREAMS-Estimation of material, energy and $\mathrm{CO}_{2}$ flows for model systems in the context of non-energy use, from a life cycle perspective-Status and scenarios; Technical Report; Fraunhofer Institute for Systems and Innovation Research (ISI): Karlsruhe, Germany, 1999; Vol. I.

(17) Vink, E. T. H.; Hettenhaus, J. R.; Dale, B. E.; Kim, S.; Fairchild D. The Life Cycle of Natureworks Polylactide: The Production of Dextrose via Corn Wet Milling, unpublished study. NatureWorks LLC: Minnetonka, Minnesota, 2004.

(18) Vink, E. T. H.; Hettenhaus, J.; O'Connor, R. P.; Dale, B. E.; Tsobanakis, P.; Stover, D. The Life Cycle of Natureworks Polylactide: The Production of Dextrose via CornWet Milling. Unpublished study. NatureWorks LLC, Minnetonka, Minnesota, 2004.

(19) Boustead, I.; Panvalkar, S. G. Eco-profiles of the Systems Used to Produce Starch and Related Products (Confidential); Technical report; Association des Amidonneries de Crales de l'UE (ACC): Brussels, Belgium, 2001.

(20) Damen, K. Future prospects for biofuel production in Brazil;A chain analysis comparison of ethanol from sugarcane and methanol from eucalyptus in Sao Paulo state. Master thesis NWS-E-2001-31, Utrecht University, Utrecht, The Netherlands, 2001.

(21) Macedo, I. C. Greenhouse gas emissions and bio-ethanol in Brazil. Int. Sugar J. 1998, 100 (1189), 2-5.

(22) Aden, A.; Ruth, M.; Ibsen, K.; Jechura, J.; Neeves, K.; Sheehan, J.; Wallace, B. Montague, L.; Slayton, A.; Lukas, J. Lignocellulosic Biomass to Ethanol Process Design and Economics Utilizing CoCurrent Dilute Acid Prehydrolysis and Enzymatic Hydrolysis For 
Corn Stover; Technical report; National Renewable Energy Laboratory (NREL): Golden, Co, 2002.

(23) Kuyper, M.; Toirkens, M. J.; Diderich, J. A.; Winkler, A. A.; van Dijken, J. P.; Pronk, J. T. Evolutionary engineering of mixedsugar utilization by a xylose-fermenting Saccharomyces cerevisiae strain. FEMS Yeast Res. 2005, 5 (10), 925-934.

(24) Alles, C. Confidential Information on 1,3-PDO Production; Personal Communicaiton, 2003.

(25) Vink, E. T. H. Confidential Information on Lactic Acid and Input for Lactic Acid Production; Personal Communicaiton, 2005.

(26) Linton, J. D.; Nisbet, T. Confidential-What is the potential impact of the ongoing developments in Biotechnology upon the economic competitiveness of the product and feedstock slate of Shell Chemicals, Shell International Chemicals BV, Personal Communication, 2003.

(27) Dielissen, M.; Weusthuis, R. A. Confidential Information on PHA Production, Personal Communication, 2004.

(28) Lysine-Sulfate Production By Fermentation with Recovery by Spray Drying; Technical Report PEP 97-8; SRI Consulting: Menlo Park, CA, 1999.

(29) Chemicals from Renewable Resources; Technical Report PEP 236; SRI Consulting: Menlo Park, CA, 2001.
(30) Biotechnology Separation Processes; Technical Report PEP 188B; SRI Consulting: Menlo Park, CA, 2002.

(31) Boustead, I. Eco-profiles of Plastics and Related Intermediates (About 55 Products); Technical report; Association of Plastics Manufacturers in Europe (PlasticsEurope): Brussels, Belgium, 1999-2005.

(32) Dornburg, V.; Termeer, G.; Faaij, André P. C. Economic and greenhouse gas emission analysis of bioenergy production using multi-product crops-case studies for the Netherlands and Poland. Biomass Bioenergy 2005, 28 (5), 454-474.

(33) Quirin, M.; Gärtner, S. O.; Pehnt, M.; Reinhardt, G. A. CO Mitigation through Biofuels in the Transport Sector-Status and Perspectives; Technical report; Institut f. Energie- und Umweltforschung (IFEU) Heidelberg GmbH: Heidelberg, Germany, 2004.

(34) Weissermel, K.; Arpe, H.-J. Industrial Organic Chemistry, 4th ed.; Wiley-VCH: Weinheim, Germany, 2003.

Received for review October 25, 2006. Revised manuscript received May 9, 2007. Accepted August 22, 2007.

ES062559Q 